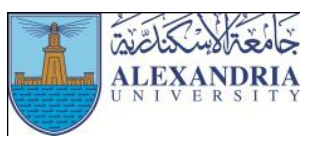

\title{
The Effect of Zumba Fitness on Some Anthropometric Measurements and Flow State for the Female Students of University of Jazan
}

\author{
Saly Mohamed Abou-Waly ${ }^{1}$ \\ ${ }^{1}$ Lecturer at the Exercises and Gymnastics Department - Faculty of Physical Education - Sadat City University, Egypt
}

\begin{abstract}
Through the work of the researcher as a supervisor of activity at the gymnasium of the Faculty of Arts and Sciences in Sametah, University of Jazan, Saudi Arabia she noted the prevalence of obesity among the female students who attend the gym as a result of lack of movement due to the technological development of devices and equipment used in daily life as well as lack of continuous training on sports equipment of the gym, so the researcher attempted to study this problem through the use of Zumba fitness for the beginners to find out its impact on some anthropometric measurements (weight loss - chest perimeter - waist perimeter - buttocks perimeter - fat percentage), also to find its effect on mood (flow state) for obese female students at the Faculty of Sciences and Arts in Sametah, University of Jazan, Saudi Arabia.
\end{abstract}

Introduction and research problem:

$\mathrm{E}$ xercise no longer has the traditional form which most of the students find it difficult to perform and repel it, as many modern techniques of physical fitness exercise have been introduced to the traditional methods, and merged with several international dances, and this results in spreading in the Arab world recently what is known by Zumba fitness, which received an overwhelming response, in addition to the presence of fun and vitality.

Zumba fitness is a Colombian fitness program, created by Beto Perez in the nineties; it depends on integration of a different group of Latin dance such as: Samba, Salsa, Reggaeton, Cumbia, Merengue and Belly Dance along with aerobic exercises associated easy Latin tunes. (29)

Zumba fitness can help burning between 400:800 calories in just an hour hour, this type of exercise depends on a light warm-up by a type of quiet music, and then begin to gradually increase the speed of movements. (25)

Zumba fitness also is very enjoyable as it is a collective activity helps in achieving fitness goals, and have many benefits, including the following: losing weight and fighting obesity; strengthening the muscles; improving the mood, refining the mind; increasing self-confidence; improving cardiovascular efficiency; helps the mind and body to work in sync with each other; achieving pleasure and happiness, all of these were confirmed by many studies carried out in this area, including the studies of
Milijana Andriana, Vladimir, (2014) (11), Nabil, Mary (2014) (19), Sridevi, Kent, Christina (2015) (20) Sevein, Andreas, Peter (2014) (21) Okonkwo N. M. (2012) (15) Svein, Peter, Sarah, Andreas (2013) (19). Practicing sport in general and Zumba fitness in particular raise the level of endorphin hormone which is responsible for the sense of happiness. (26) (27) (28)

Through the work of the researcher as a supervisor of activity at the gymnasium of the Faculty of Arts and Sciences in Sametah, University of Jazan, Saudi Arabia she noted the prevalence of obesity among the female students who attend the gym as a result of lack of movement due to the technological development of devices and equipment used in daily life as well as lack of continuous training on sports equipment of the gym, so the researcher attempted to study this problem through the use of Zumba fitness for the beginners to find out its impact on some anthropometric measurements (weight loss - chest perimeter - waist perimeter - buttocks perimeter - fat percentage), also to find its effect on mood (flow state) for obese female students at the Faculty of Sciences and Arts in Sametah, University of Jazan, Saudi Arabia.

Flow state is a very important concept related to positive psychology which was introduced by the Hungarian American psychologist (Mihaly Csikszentmihalyi, 1990) where he defined it as an internal psychological condition makes the student feel autism while trying to focus in the activities, rush actively towards those activities, with low 
awareness of time and place, forgetting the needs of self, feeling of joy, happiness and pleasure of doing the work, and this is a condition of preoccupation of the student when she is busy doing a preferred job. $(6,14)$

Flow state as a positive phenomenon in sports psychology plays an effective role in using all intellectual, physical, skillful and tactical ability to serve in achievement or sports performance. During this process the student thinks about nothing but performing her duties with a state of joy and ecstasy along with a sense of the value of the performance and its meaning and dedicates her life to achieving the goals she has drawn to herself by giving effort in the process. $(6,3)$

\section{Terms used in the research:}

\section{1- Zumba fitness:}

A type of aerobics which integrates different types of Latin dance and easy rhythmic technical exercise to move a large number of body muscles associated with some sort of music. (22)

\section{2- Anthropometric measurements:}

Studying the human body measurements which include (height, weight, size, perimeter of the whole body, and the various parts of the body) $(10,236)(9,20)$

\section{3- Flow state:}

A positive psychological state that makes a person feel autism with what he/she is doing, focus on the value of this action and rush actively with a general sense of success towards this activity. (6-7)

\section{Research goals:}

Identifying the effect of Zumba fitness on:

1- Some anthropometric measurements of the female students of the University of Jazan.

2- Flow state of the female students of the University of Jazan.

3- The rate of improvement in some anthropometric measurements and the flow state of the female students of the University of Jazan.

\section{Research hypotheses:}

1- There are statistically significant differences between the pre- and post-measurements in the experimental group in some anthropometric measurements in favor to the postmeasurement.
2- There are statistically significant differences between the pre- and post-measurements in the experimental group in flow state in favor to the post-measurement.

3- There is an improvement for some anthropometric measurements and the flow state for the female students of the University of Jazan.

\section{Research procedures:}

\section{- Research methodology:}

The researcher used the experimental method, because it is appropriate to the nature of the study, with using the experimental design to one experimental group through pre- and post-measurements.

\section{- Spheres of the research:}

\section{1- Geographical sphere:}

The gymnasium of the Faculty of Sciences and Arts in Sametah, University of Jazan, Saudi Arabia

\section{2- Temporal sphere:}

The program was applied in the second semester of the academic year 2014/2015 from Sunday 15/2/2015 to Thursday 23/4/2015 three times per week with $(90$ minutes) for each unit. The program took ten weeks to be completed.

\section{3- Human sphere:}

Obese female students at the Faculty of Arts and Sciences in Sametah

\section{- Research sample:}

The research sample consisted of (30) students who were intentionally selected from the students who attend the gym of the Faculty of Arts and Sciences in Sametah, Jazan University, Saudi Arabia in the academic year 2014/2015, they were obese according to the latest indicators of obesity (if the body is overweighed by about $15 \%$ to the normal weight of women so it is obese, taking into account the length, size, gender and age) $(5,137)$. (10) of the students were chosen from the research community, outside the research sample for the pilot study.

\section{- Homogeneity of the research group:}

Homogeneity of the sample was confirmed due the variables of (height, weight, age, chest perimeter, waist perimeter, buttocks perimeter, weight of fats, and the flow state measurement) to make sure that the students of the research sample were under the equinoctial curve, as shown in Table (1). 
Table (1)

Statistical significance of the research sample in the research variables prior to the experiment $(\mathrm{N}=30)$

\begin{tabular}{|c|c|c|c|c|c|c|}
\hline \multicolumn{2}{|c|}{$\mathrm{N}_{\text {Variables }}^{\begin{array}{r}\text { Statistical } \\
\text { significance }\end{array}}$} & $\begin{array}{c}\text { Arithmetic } \\
\text { mean }\end{array}$ & Median & $\begin{array}{l}\text { Standard } \\
\text { deviation }\end{array}$ & $\begin{array}{l}\text { Torsion } \\
\text { coefficient }\end{array}$ & $\begin{array}{l}\text { Flattening } \\
\text { coefficient }\end{array}$ \\
\hline \multirow{3}{*}{ Basic variables } & Length & 157.30 & 158.00 & 4.43 & -0.07 & 0.07 \\
\hline & Age & 20.17 & 20.00 & 0.95 & 0.16 & -1.04 \\
\hline & Weight & 89.95 & 88.50 & 11.97 & 0.41 & 2.31 \\
\hline \multirow{4}{*}{$\begin{array}{l}\text { Perimeters and } \\
\text { weight of fats }\end{array}$} & $\begin{array}{c}\text { Chest } \\
\text { perimeter }\end{array}$ & 108.70 & 107.50 & 11.38 & 1.04 & 0.53 \\
\hline & Waist perimeter & 115.13 & 115.00 & 8.96 & -0.25 & -0.12 \\
\hline & $\begin{array}{l}\text { Buttocks } \\
\text { perimeter }\end{array}$ & 123.57 & 121.00 & 8.90 & -0.31 & -0.10 \\
\hline & Weight of fats & 0.96 & 1.00 & 0.06 & 0.33 & -0.82 \\
\hline \multicolumn{2}{|c|}{ Flow measurement } & 22.63 & 22.50 & 0.72 & 0.69 & -0.70 \\
\hline
\end{tabular}

Table (1) shows that the data of the total research sample is dispersed and moderate and also characterized by normal distribution, where the torsion coefficient value ranged between (-0.31 and 1.04), and these values are close to zero, which confirms the moderation of the data of the research sample prior to the experiment.

\section{Means of data collection:}

\section{1- Instruments and tools:}

Restameter to measure the height $(\mathrm{cm})$, a medical scale to measure the weight $(\mathrm{kg})$, the measuring tape to measure the body's parameter $(\mathrm{cm})$

\section{2- Forms:}

- A form for data collection of the sample individuals of the variables. Attachment (1)

\section{3- Tests:}

- Flow state scale, the Arabic version was prepared by Magdy Youssef (2014) Attachment (2) - the test of percentage of fats, Attachment (3)

\section{- Scientific coefficients for the flow state:}

\section{1- Validity of the test:}

The researcher calculated the validity of the flow state using the two-side comparison by differentiating between the highest quarters and the lowest quarters, Table (2) shows the validity of the test.

Table (2)

Validity of the two-side comparison for the flow state test $(\mathrm{N}=10)$

\begin{tabular}{|c|c|c|c|c|c|c|c|c|}
\hline $\begin{array}{r}\text { Statistical } \\
\text { sionificance }\end{array}$ & \multicolumn{2}{|c|}{ Highest quarters } & \multicolumn{2}{|c|}{ Lowest quarters } & $\begin{array}{c}\text { Mann } \\
\text { Whitney (U) }\end{array}$ & $\begin{array}{l}\text { Wilcoxon } \\
\text { (W) }\end{array}$ & \multirow{2}{*}{$\mathrm{Z}$} & \multirow{2}{*}{$\mathrm{P}$} \\
\hline Variable & $\pm \sigma$ & $\pm \sigma$ & $\mathrm{x}$ & $\mathrm{x}$ & $\pm \sigma$ & $\mathrm{x}$ & & \\
\hline Flow state scale & 35.11 & 1.31 & 54.10 & 1.11 & Zero & 55 & 4.175 & $0.000 *$ \\
\hline
\end{tabular}

$* \mathrm{~d}$ at $0.05(\mathrm{P}<0.05)$

Table (2), shows that the differences between the highest and lowest quarters are statistically significant, and this confirms the validity of the test and that it discriminates between its different levels.
Reliability of flow state scale was found by calculating the (t) value calculated by comparing between the first and second applications, Table (3) shows the stability of the test.

\section{2- Reliability of the test:}


Table (3)

The comparison between the first and second applications to find the reliability of flow state test $(\mathrm{N}=10)$

\begin{tabular}{|c|c|c|c|c|c|c|c|}
\hline \multirow{2}{*}{ Variable } & \multicolumn{2}{|c|}{ Pre-measurement } & \multicolumn{2}{|c|}{ Post-measurement } & \multicolumn{2}{|c|}{$\begin{array}{c}\text { Difference between the two } \\
\text { measurements }\end{array}$} & \multirow[t]{2}{*}{ (t) value } \\
\hline & $\pm \sigma$ & $\mathrm{x}^{\wedge}$ & $\pm \sigma$ & $\mathrm{x}^{\wedge}$ & $\pm \sigma$ & $\mathrm{x}^{\wedge}$ & \\
\hline Flow state scale & 22.53 & 1.51 & 23.00 & 0.93 & 1.77 & 0.46 & 1.02 \\
\hline
\end{tabular}

* Significant at $0.05=2.15$

Table (3) shows that there were no statistically significant differences at the level of $(0.05)$ as the calculated $(\mathrm{t})$ value was (1.02) which is less than the indexed $(t)$ value at $(0.05)=(2.15)$ which indicates the reliability of flow state scale.

\section{Research procedures:}

\section{- Pre-measurements:}

Pre-measurements were made from Wednesday 11/2/2015 until Thursday 12/2/2015, and they included (weight, chest perimeter, waist perimeter, buttocks perimeter, weight of fats and flow state scale).

\section{- The proposed program: Attachment (4)}

- Zumba fitness is a modern aerobic activity, which appeared recently in the Arab world. Moderate aerobic activities help to strengthen the heart muscle and be more efficient, and lead to more consumption of calories and losing weight. $(7,6)$, practicing this exercise slowly (4) times for (20-30) minutes has a positive impact on the students who did not practice physical activity before. (18) So the researcher identified the following:

- The period of applying the program took 10 weeks, from Sunday $15 / 2 / 2015$ to Thursday 23/4/2015.
- Number of weekly workouts: (3) units

- Duration of each module (90) min.

- Medium intensity was identified as (60-70\%) with a rate of pulse (140-152 beats per second), and this reflects the required pulse since the required pulse $=$ the percentage of training \% (Maximum pulse - resting pulse) + resting pulse where the maximum pulse is 220 - age of the trainee, resting pulse is 70 beats / $\min$. (17)

- The program included:

1. The basic steps of Zumba fitness (Salsa, Cumbia, Reggaeton and Merengue)

2. The music associated was identified (1/1), and it is fast and powerful (Reggaeton and Merengue), and medium and slow music (Salsa and Cumbia). This type of exercise depends on light warm-up through quiet music, and then gradually begins to rise with increasing the speed of the movements. (26)

- The researcher divided the period of applying the program into three phases, each one has its characteristics as following:

\begin{tabular}{|c|c|}
\hline weeks & Characteristics of each phase \\
\hline 1,2 & $\begin{array}{c}\text { Module duration (60-70) min., used music 1/1 is positive quick song (Reggaeton and Merengue), then medium (Salsa and } \\
\text { Cumbia) and rest } 1 \text { sec. after each group 1/1 }\end{array}$ \\
\hline $3,4,5,6$ & Module duration (70-80) min., used music 2/1, rest 1 sec. after each group 2/1 \\
\hline $7,8,9,10$ & Module duration (90) min., used music 2/1, rest 1 sec. after each group 2/1 \\
\hline
\end{tabular}

- The exercises must be mastered to be able to perform Zumba fitness easily with flexibility and agility as follows: The first exercise is the method of breathing inhalation of nasal air and take it out deeply of the mouth so the student can perform the exercise without fatigue, the second exercise the student puts her left hand on the wall and the right one on her waist and raise the right leg, while she is standing on the left leg on the fingertips, then change to the other side and do the same thing, the third exercise starts with standing on the fingertips wearing sport shoes, then moving the heels up and down without lifting the foot from the ground while breathing as mentioned before, putting the hands on the waist and moving it, the exercise begins when the student stands against the wall and put her hands on the wall at the level of the shoulders and jump, and it gradually starts, the fourth exercise starts with balanced standing, so that no one can push you and drops you down on the ground, this is done with opening the legs as wide as the shoulders' length, the fifth exercise is done by getting the legs back to the buttocks while raising the hands behind the neck, and having them back while taking steps forward and backward then right and left, the sixth exercise quick walk in the same place, with lifting the knee up to the front, bending the hands at the level of the chest and making the butterfly move quickly. (24) 


\section{- Conditions of successful anthropometric measurements:}

Measuring is done while the performer is wearing light clothes, unifying the people who measure and the used devices, when the measurements performed on adult females make sure that they are not in the menstrual cycle period during the measurements, also a closed place must be ready for performing these measurements, and the measurements must be recorded precisely in the form according to the instructions, the individuals who measure must be completely aware of the following: the anatomical points to be measured, the performer's positions during measurement, methods of using tools, conditions of technical and organizational measurements and applying them precisely. $(8,123-124)$

\section{- Post-measurements:}

Post-measurements were conducted from Saturday $25 / 4 / 2015$ to Sunday 26/4/2015 for the experimental group regarding (weight, chest perimeter, waist perimeter, buttocks perimeter, fats percentage and flow state).

\section{Statistical treatments:}

The statistical data was analyzed according to the following statistical methods:

- The arithmetic mean, median, standard deviation, torsion coefficient, flattening coefficient, the $(\mathrm{t})$ value, the rate of improvement, Mann Whitney, and Wilcoxon.

\section{Presentation and discussion of the results:}

Results of the experimental group before and after the experiment; Table (4) shows them.

Table (4)

Statistical significance of the variables of the experimental group before and after the experiment $(\mathrm{N}=30)$

\begin{tabular}{|c|c|c|c|c|c|c|c|c|c|}
\hline \multirow{2}{*}{\multicolumn{2}{|c|}{ Variable }} & \multicolumn{2}{|c|}{ Pre-measurement } & \multicolumn{2}{|c|}{ Post-measurement } & \multicolumn{2}{|c|}{$\begin{array}{l}\text { Difference between } \\
\text { the medians }\end{array}$} & \multirow{2}{*}{ (t) value } & \multirow{2}{*}{$\begin{array}{c}\text { Percentage of } \\
\text { improvement } \\
\%\end{array}$} \\
\hline & & $x^{\wedge}$ & $\pm \sigma$ & $\mathrm{x}^{\wedge}$ & $\pm \sigma$ & $x^{\wedge}$ & $\pm \sigma$ & & \\
\hline \multicolumn{2}{|c|}{ Weight } & 89.95 & 11.97 & 82.27 & 10.63 & 7.68 & 6.72 & $6.26^{*}$ & 8.54 \\
\hline \multirow{4}{*}{ 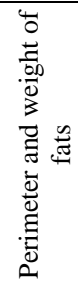 } & $\begin{array}{c}\text { Chest } \\
\text { perimeter }\end{array}$ & 108.70 & 11.38 & 103.63 & 11.19 & 5.07 & 0.45 & $61.70^{*}$ & 4.66 \\
\hline & $\begin{array}{c}\text { Waist } \\
\text { perimeter }\end{array}$ & 115.13 & 8.96 & 106.90 & 8.80 & 8.23 & 5.82 & $7.75^{*}$ & 7.15 \\
\hline & $\begin{array}{l}\text { Buttocks } \\
\text { perimeter }\end{array}$ & 123.57 & 8.90 & 116.00 & 8.92 & 7.57 & 2.10 & $19.78^{*}$ & 6.12 \\
\hline & Weight of fats & 0.96 & 0.06 & 0.85 & 0.06 & 0.11 & 0.03 & $23.03 *$ & 11.15 \\
\hline \multicolumn{2}{|c|}{ Flow scale } & 22.63 & 0.72 & 106.90 & 1.24 & 84.27 & 1.36 & $338.65^{*}$ & 372.31 \\
\hline
\end{tabular}

* Significant at the level of $0.05=2.05$

Table (4) and Figures (1), (2), (3), and (4) show that there were statistically significant differences at the level (0.05) and the calculated $(\mathrm{t})$ value ranged between (6.26 to $338.65)$, all of which are greater than the tabulated $(t)$ value at the level $(0.05)=(2.05)$ while the percentage of improvement ranged between $(4.66 \%$ to $372.31 \%)$ in favor of the post-measurement. 
Figures $(1,2,3$, and 4$)$

The comparison between the pre- and post-measurements for the experimental group of the variables of the study

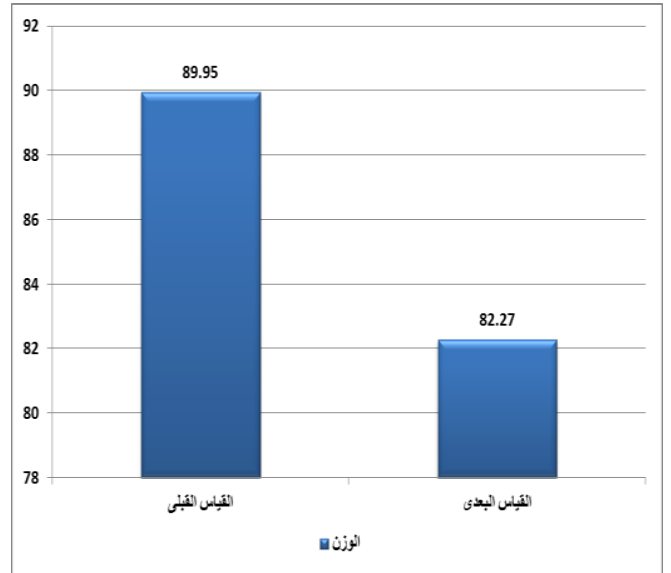

Figure (1)

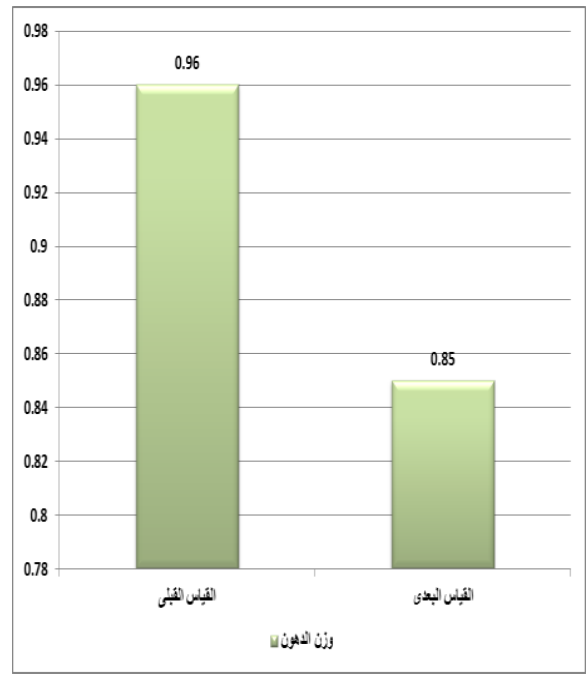

Figure (3)

Table (4) and Figures (1), (2), and (3) show that there were statistically significant differences at the level (0.05) between the (pre- and post-measurements) in the experimental group regarding (weight - percentage of fat - chest perimeter - waist perimeter - buttocks perimeter) as the calculated $(\mathrm{t})$ value ranged between (6.26 to $338.65)$, all of which are greater than the tabulated $(t)$ value, as a result the researcher noted that these findings are due to applying the program of Zumba fitness which led to losing (weight, chest perimeter, waist perimeter, buttocks perimeter, and weight of fat) for the students of the research sample. This workout is ranked number one among all types of exercises that help burning fats and tightening the body. (25)

(Bob et.al. 2000) pointed that when Zumba fitness is practiced regularly for a long time this would increase the energy consumption and will decrease the fat percentage

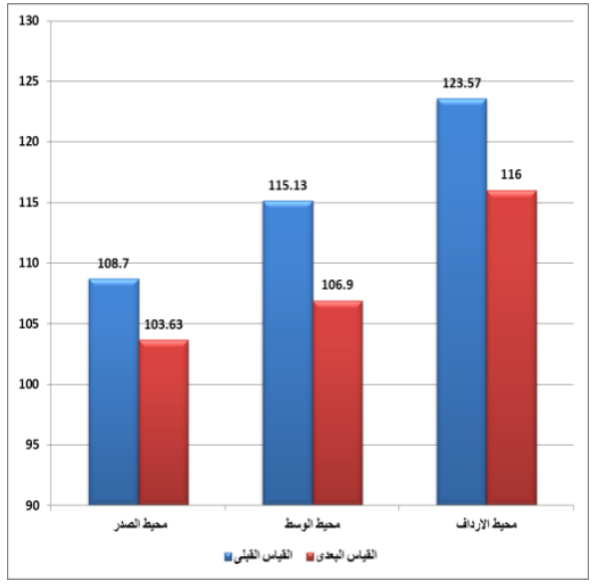

Figure (2)

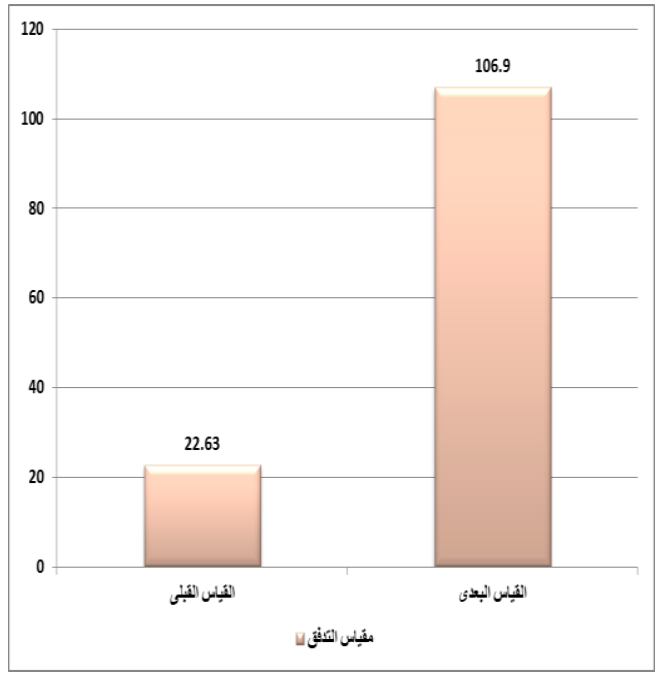

Figure (4)

in the body. (108, 13), while (Aed Fadel 1999) confirms that there is no exact exercise can remove fats from a certain area of the body rather than the other, but the fat is decomposed of the body according to the intensity of accumulation, which means many accumulate in fats decomposes many quantities more than the areas which have less fats. $(195,4)$ Since the outcomes of regular Zumba fitness lead to reduce the fatty tissue around the muscular fiber, so the lack of peripheral and weight measurements and body fat percentage is due to the lack of fatty tissue. $(122,12)$, so the first hypothesis is achieved. These results conformed to the studies of each of "Adriana, Vladimir" (2014) (11), "Nabil, Mary" (2014) (19), "Domene, Moir, Pamell, Knox, Easton" (2015) (16), "Sridevi, Kent, Christina," (2014) (20), "Okonko (2012) (15), "Sevein Baren, Pter" (2014) (21). 
In the meantime Table (4) and Figure (4) show that there were statistically significant differences at the level (0.05) between the (pre- and post-measurements) in the experimental group regarding the flow state as the $(t)$ value was $=338.65$, and thus the proposed program of Zumba fitness positively affected the level flow state of the students of the research sample, where Zumba fitness works on improving the mood, and liquidating the mind. (23) We also find that the flow state plays an important role to achieve valuable sporting achievement (12) so the second hypothesis is achieved.

Table (4) also shows that there is a percentage of improvement between the (pre- and post-measurements) for the experimental group where percentage of improvement ranged between (4.66\% and $372.31 \%$ ) in favor of the post-measurement. so the third hypothesis is achieved. Therefor it is obvious that the program of Zumba fitness had a positive effect in order to achieve those results.

\section{Conclusions:}

The researcher concluded the following:

1- Zumba fitness reduced the anthropometric measurements in (weight - chest perimeter - waist perimeter - buttocks perimeter - percentage of fat).

2- Zumba fitness had a positive effect on the flow state.

3- The results of post-measurements exceeded in the experimental group in the percentage of improvement regarding (weight - chest perimeter - waist perimeter buttocks perimeter - percentage of fat - flow state).

\section{Recommendations:}

Taking into consideration the research sample and the results the researcher recommends the following:

1- Using Zumba fitness for losing weight and some anthropometric measurements.

2- Using Zumba fitness to improve the flow state of the students.

3- Further studies on other anthropometric, physiological and psychological measurements could be made on Zumba fitness

\section{References:}

1- Ibrahim Ahmed Sallam (2000): Applied Introduction for Measuring Physical Fitness, Mansha'at Al-Maaref Alexandria.
2- Abou-Elela Abdel-Fattah (2003): Physiology of Sports Training, Cairo, Dar Al-Fikr Al-Araby.

3- Aaed Fadel Melhem (1999): Sport Medicine and Physiology, Contemporary Issues and Problems, Dar AlKendy for Publishing and Distribution.

4- Amer Ibrahim Kandeligy (1999): Scientific Research and Using Information Sources, Dar Al-Bazory, Amman.

5- Adnan Saleh Abu-Lawy (1987): The Dominant Energy System in Sports Activity and Its Impact on Fat and Protein in the Blood, Unpublished PhD Thesis, Faculty of Physical Education, University of Baghdad.

6- Magdy Hassan Yousef (2014): Phenomenology of Flow State in Sport Field, Al-Alamiya for Publishing and Distribution, Alexandria, Egypt.

7- Mohamed El-Said Abdel-Gawad Abou-Halawah (2013): Flow State Concept - Aspects - Measurement Outside the Serial Version of the Book Network, Issue 29, E-Book Web of Science and Technology.

8- Mohamed Sobhy Hassanein (1987): Measurement and Evaluation in Physical Education, Dar Al-Fikr Al-Araby Egypt.

9- Mohamed Nasreddin Radwan (1997): Reference of Physical Measurements, Dar Al-Fikr Al-Araby - Cairo.

10- Nizar Al-Taleb, Mahmoud Al-Samerrany (1981): Principles of Physical and Sport Tests, Mosul University Press, Iraq.

11- Adriana Ljubojević1, Vladimir Jakovljević1, and Milijana Popržen2 (2014), Effects of Zumba Fitness Program on Body Composition of Women, SportLogia, 10(1), 29-33

12- Bob D, Ros B.Jan R.Demnis R(2000): Physical Educatin and study of sport 4ed. Harout. Pubishers.

13- Csikszentmihaly, M.(1990): Flow the Psyehology of optimal experience, New York, Harper\& row.

14- Date: October 2012 Okonkwo, N.M. (2012). Energy expenditure and physiological responses to 60 minute Zumba aerobic sessions (group class versus home) in healthy adult females. (Unpublished master's thesis). University of Chester, United Kingdom.

15- Domene, P. A., Moir, H. J., Pummell, E., Knox, A., Easton, C. (2015). The health-enhancing efficacy of Zumba fitness: An 8-week randomised controlled study The health-enhancing efficacy of Zumba® fitness: An 8 wk randomised controlled study. Journal of Sports Sciences . 
16- Fox, E, I, and Mishews, D,K;(1974) interval: conditions For sport general fitins, W, 13 sunders company.

17- Moore,N,etal: (1988): The effects of 12 weeks low impact Aerobic Dance Traning in sedentary and Trained individuals Medcine for spert Exec vol 20 p 89.

18- Nabil E Boutagy, Mary Yoke(2011) : The Energy Cost of Zumba Exercise Medicine \& Science in Sports \& Exercise.

19- Sridevi Krishnan ,Kent Griffin , Christina Esperat, (2015) Zumba Dance Improves Health in Overweight/Obese or Type 2 Diabetic Women American journal of health behavior, 39(1):109-120.

20- Svein Barene, Andreas Holtermann, Peter Krustrup, 2014 Soccer and Zumba as health-promoting activities among female hospital employees: A 40-weeks cluster randomised intervention study, Journal of Sports Sciences, Vol. 32, No. 16, 1539-1549.

21- Supermamy. net/ Vb/Showthread php?

Websites

22- http://Sportywo.blogespot.com.eg.

23- http://vetogate.com.

24- www.albawaba.com?ar 555212.

25- www. Alwatan voice.com/ Arabic/news/ 2014/14/522555.html.

26- www. Fastbodys limming.com?p: 1053

27- www. Koniqueen. Com.

28- www. Weziwezi.com/news?p= 9998. 